\title{
On the source of uterine 'luminal fluid' proteins in the mouse
}

\author{
L. Martin* \\ Department of Hormone Physiology, Imperial Cancer Research Fund, Lincoln's Inn Fields, \\ London WC2A $3 P X, U . K$.
}

\begin{abstract}
Summary. Examination by light-, transmission electron- and scanning electronmicroscopy showed that flushing the lumen of the mouse uterus with small volumes of fluid damaged the endometrium by rupturing and removing luminal epithelial cells, splitting the epithelial basement membrane and connective tissue stroma, and rupturing and leaching stromal cells and blood vessels. The damage increased with increasing progestation of the uterus and between Days 4 and 5 of pregnancy.

I conclude that many so-called 'luminal fluid' proteins originate from luminal and stromal cells, intercellular fluid and blood and that apparent changes in luminal fluid protein content during early pregnancy may largely reflect alterations in the extent and type of damage produced by flushing, as a consequence of changes in the physical state of the uterus induced by hormones and the presence of blastocysts.
\end{abstract}

\section{Introduction}

There has been much interest in changes which occur in the uterine luminal fluid proteins around the time of embryo implantation in rats and mice (Aitken, 1979). Samples of such proteins are usually obtained by flushing the lumen (Surani, 1975, 1977; Gore-Langton \& Surani, 1976; Pratt, 1977; Aitken, 1977). I had been puzzled by the large amounts of material so obtained from mouse uteri on Days 4-5 of pregnancy, because at this time the lumen virtually disappears, the luminal epithelial surfaces coming into such close proximity that the microvilli of the opposing surfaces interdigitate or disappear (Mayer, Nilsson \& Reinius, 1967; Martin \& Finn, 1970).

Development of a simple method of removing the uterine luminal epithelium (Fagg, Martin, Rogers, Clark \& Quarmby, 1979) made me aware of the extreme fragility of this tissue and suggested that 'luminal fluid' proteins might arise by leaching, disruption, or removal of luminal cells; hence these experiments to investigate the effects of luminal flushing on endometrial structure.

\section{Materials and Methods}

Randomly bred female Swiss Schneider mice were housed, allowed to become pregnant, or ovariectomized as described by Martin \& Finn (1979).

Pregnant mice. Intact females, 6 weeks old, were placed with males; the day of finding a vaginal plug was Day 1 of pregnancy. Mice were killed and their uteri flushed at 15:00-16:00 h on Day 4,

* Present address : Department of Physiology and Pharmacology, University of Queensland, St Lucia, Queensland 4067, Australia.

(C) 1984 Journals of Reproduction \& Fertility Ltd 
or at 10:30-11:30 $\mathrm{h}$ on Day 5. At $15 \mathrm{~min}$ before death they were anaesthetized with tribromoethanol and given $0.2 \mathrm{ml}$ of $2 \%$ Pontamine Blue i.v. in saline $(9 \mathrm{~g} \mathrm{NaCl} / 1)$ to aid detection of implantation sites.

Ovariectomized mice. At 2 weeks after ovariectomy, mice were primed with 3 daily injections of $100 \mathrm{ng}$ oestradiol-173. Some were killed and their uteri flushed at 10:00-11:00 h on Day 6 after priming and $24 \mathrm{~h}$ after 1 injection of vehicle with or without $50 \mathrm{ng}$ oestradiol-17 $\beta$. Others left untreated for 2 days after priming were then given $1 \mathrm{mg}$ progesterone with or without $15 \mathrm{ng}$ oestradiol-17 3 daily at 11:00 h. These animals were killed and their uteri flushed, between 11:00 and 15:00 h, after 2, 3 or 4 such injections. All injections were made s.c. in $0.05 \mathrm{ml}$ arachis oil. The regimen of progesterone + oestradiol- $17 \beta$ produces patterns of cell division and morphological changes like those seen in pregnancy (Finn \& Martin, 1969; Martin, Finn \& Carter, 1970). Maximal sensitivity to a decidual-inducing stimulus occurs on Day 3 of the treatment (Finn \& Martin, 1972): this corresponds to Day 4 of pregnancy, and Day 4 of treatment corresponds to Day 5 of pregnancy when embryo implantation is well advanced.

Uterine flushing. Mice were killed by cervical dislocation; uterine horns were dissected, freed of mesentery, cut through near the cervix and blotted gently on filter paper dampened with saline to remove blood. One horn was flushed via the extreme ovarian tip using a 1-or 2-ml syringe and a 26gauge needle; the other was treated identically except that fluid was not passed through the lumen. Contact with forceps or needle was restricted to the extreme cervical and ovarian tips of each horn.

Uteri were flushed rapidly $(3-4 \mathrm{sec})$ with various volumes and fluids including: $0.5 \mathrm{ml} 0.001 \mathrm{M}$ Tris-glycine buffer, exactly as described by Aitken (1977): phosphate-buffered saline (PBS) or $0.9 \%(w / v) \mathrm{NaCl}$.

Processing of tissues. Immediately after flushing, or sham-flushing, uterine horns were pinned out in ice-cold $2.5 \%$ glutaraldehyde in Soerenson's phosphate buffer, $\mathrm{pH} 7 \cdot 4$. Fragments from the mid-region of each horn were processed by normal histological techniques and $5 \mu \mathrm{m}$ paraffin wax sections were stained with toluidine blue; adjoining fragments were sometimes processed for transmission electron microscopy (TEM) as described by Fagg et al. (1979). In some cases, fragments 4-10 $\mathrm{mm}$ long from the mid-region were examined by scanning electron microscopy (SEM): after fixation, uterine horns were placed mesometrium upwards and longitudinally sliced gently through in the horizontal plane with a sharp scalpel to expose the anti-mesometrial 'lumen'. Further processing was carried out as described by Fagg et al. (1979).

\section{PLATE 1}

Figs $1 \& 2$. Transverse sections (wax, $5 \mu \mathrm{m}$; toluidine blue, $\times 80$ ) from uteri of ovariectomized mice killed on the 3 rd day of progesterone/oestrogen treatment.

Fig. 1. Sham-flushed horn; lumen is closed and luminal and stromal cells are densely packed and heavily stained.

Fig. 2. Horn flushed with $0.1 \mathrm{ml}$ PBS; lumen is open and many antimesometrial luminal cells have lost cytoplasmic and nuclear material. The epithelium and stroma are ruptured antimesometrially; the stroma is 'oedematous', many stromal cells have lost cytoplasmic and nuclear material.

Figs 3, $4 \&$ 5. Transmission electron micrographs of uterine epithelia from ovariectomized mice killed on Day 4 of progesterone/oestrogen treatment.

Fig. 3. Sham-flushed horn; lumen is closed, microvilli interdigitate. $\times 3200$.

Fig. 4. Sham-flushed horn; microvilli interdigitate. $\times 24: 000$.

Fig. 5. Flushed horn $(0.5 \mathrm{ml}$ Tris-glycine buffer); extensive vacuolation of epithelium and stroma; numerous membrane vesicles in the 'lumen'. $\times 3200$. 
PLATE 1
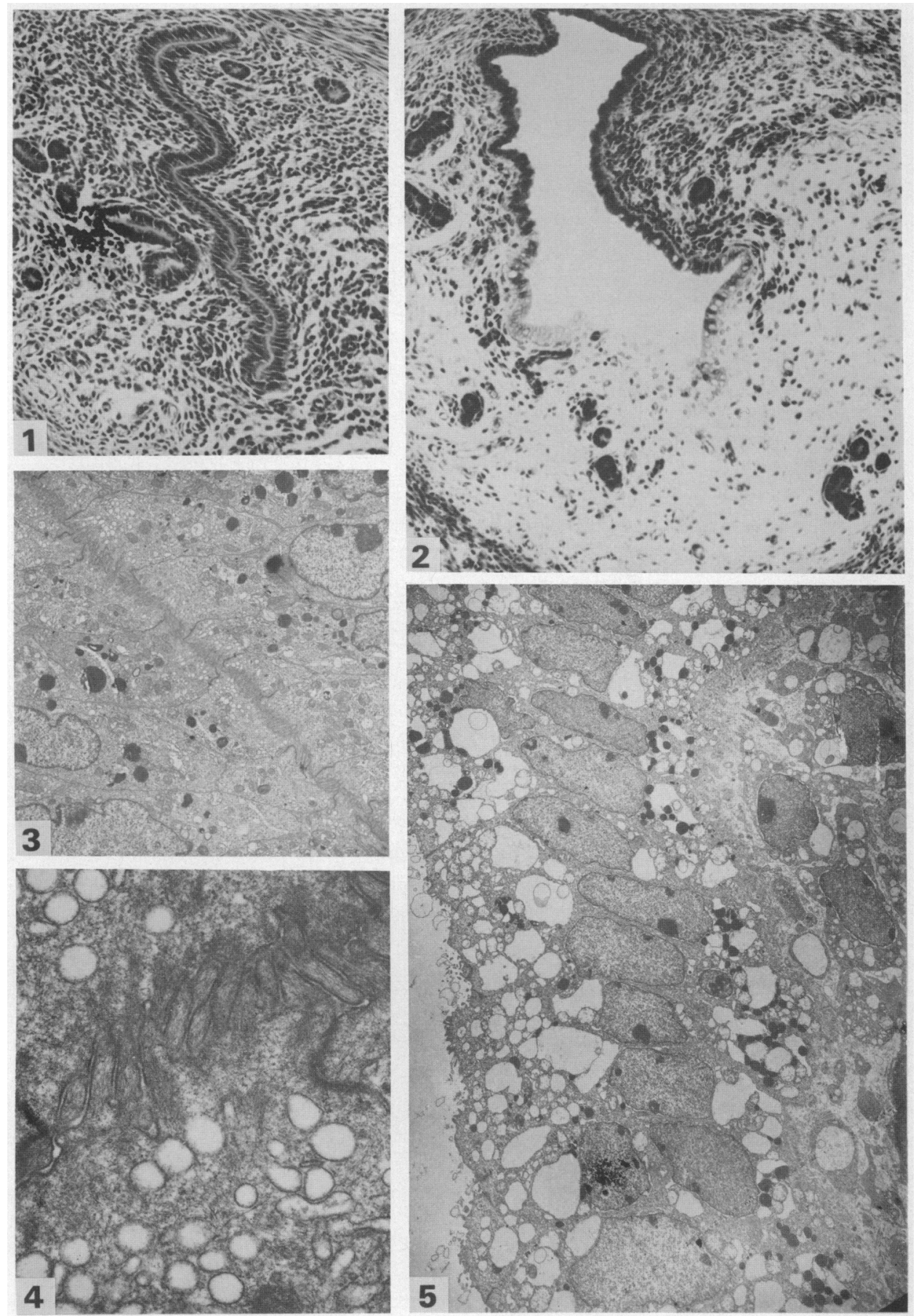
PLATE ?
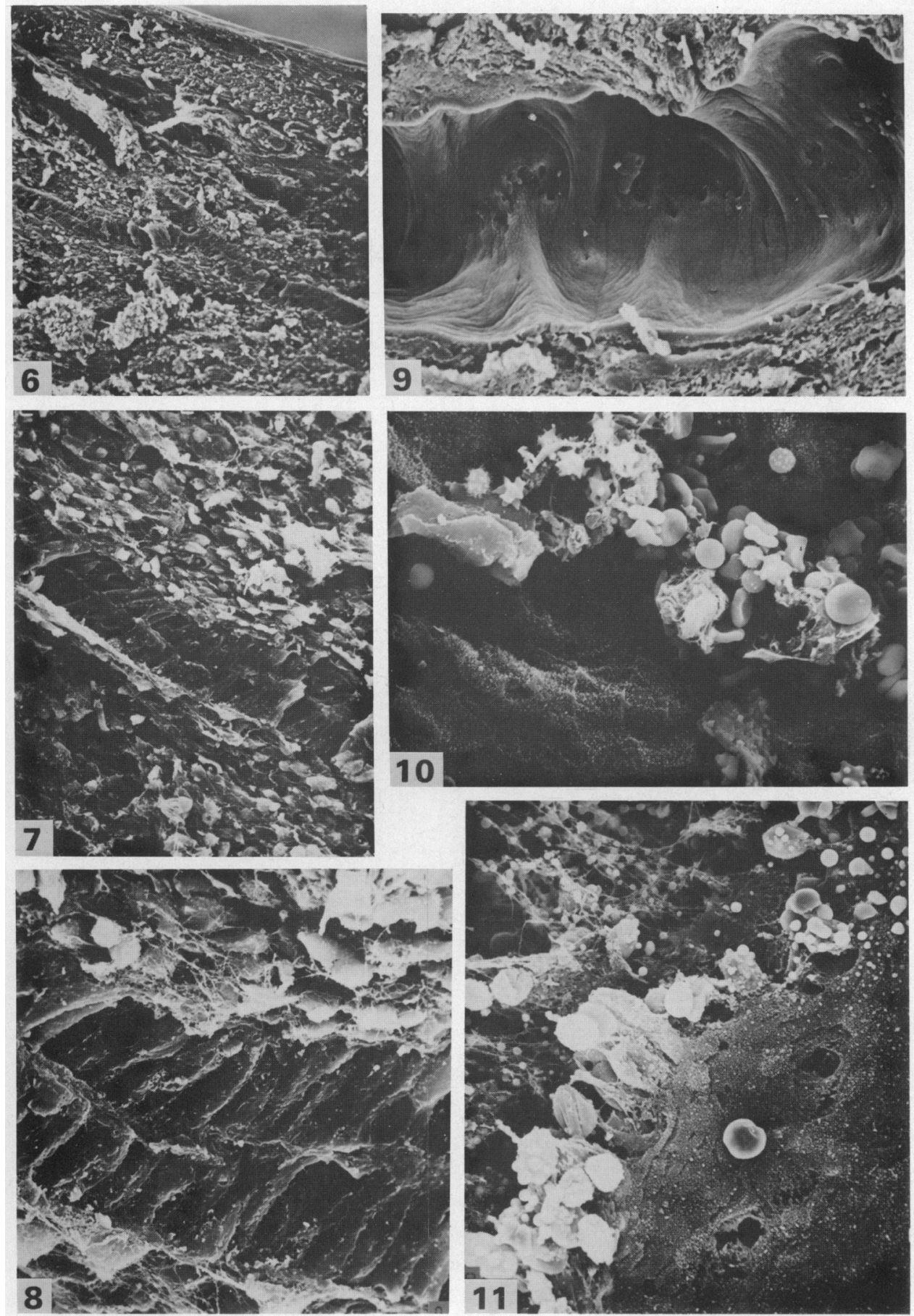


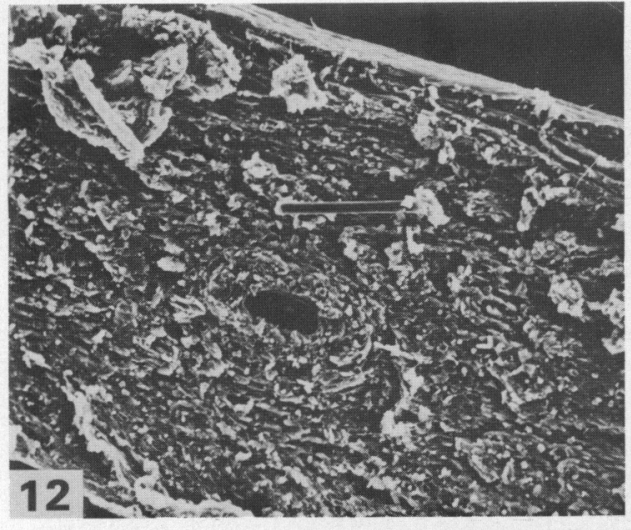

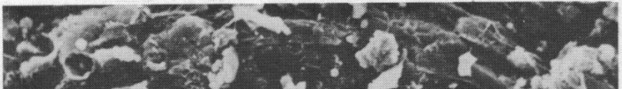

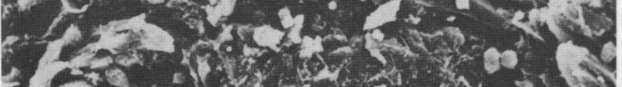

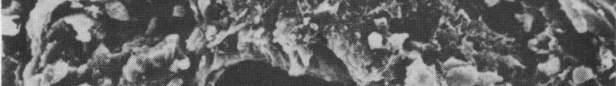
Ifxes a

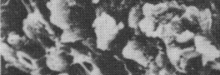

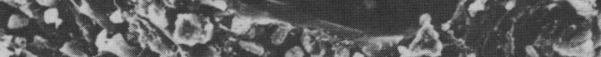

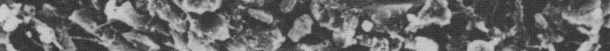

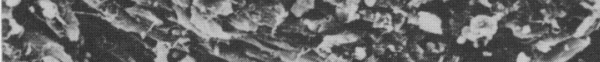

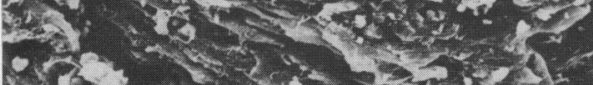

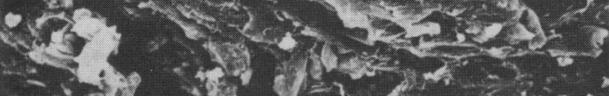

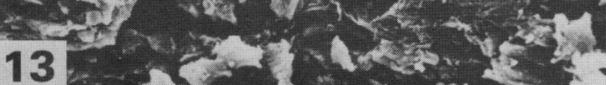

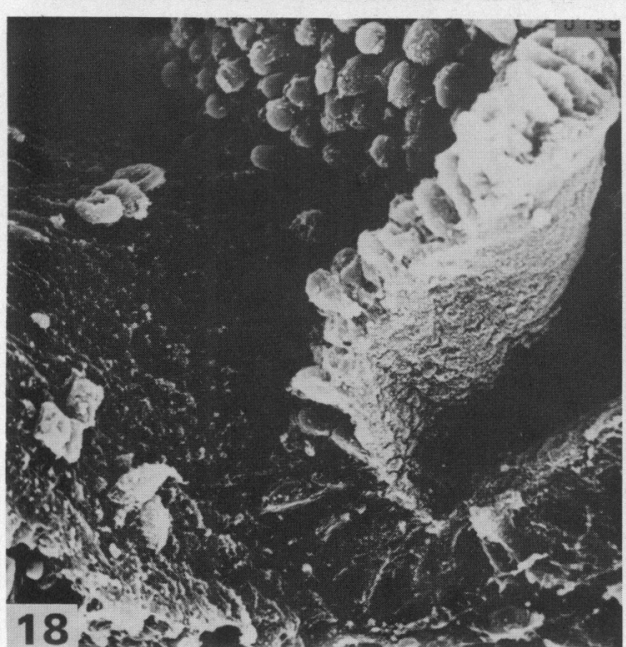

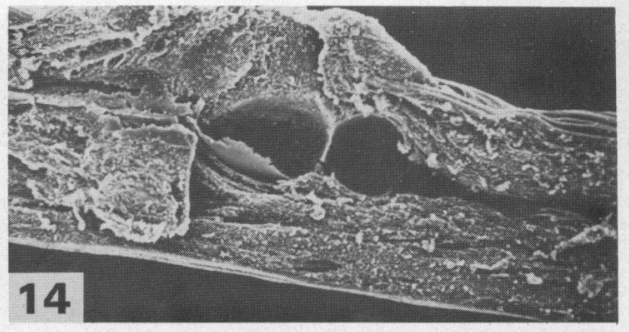
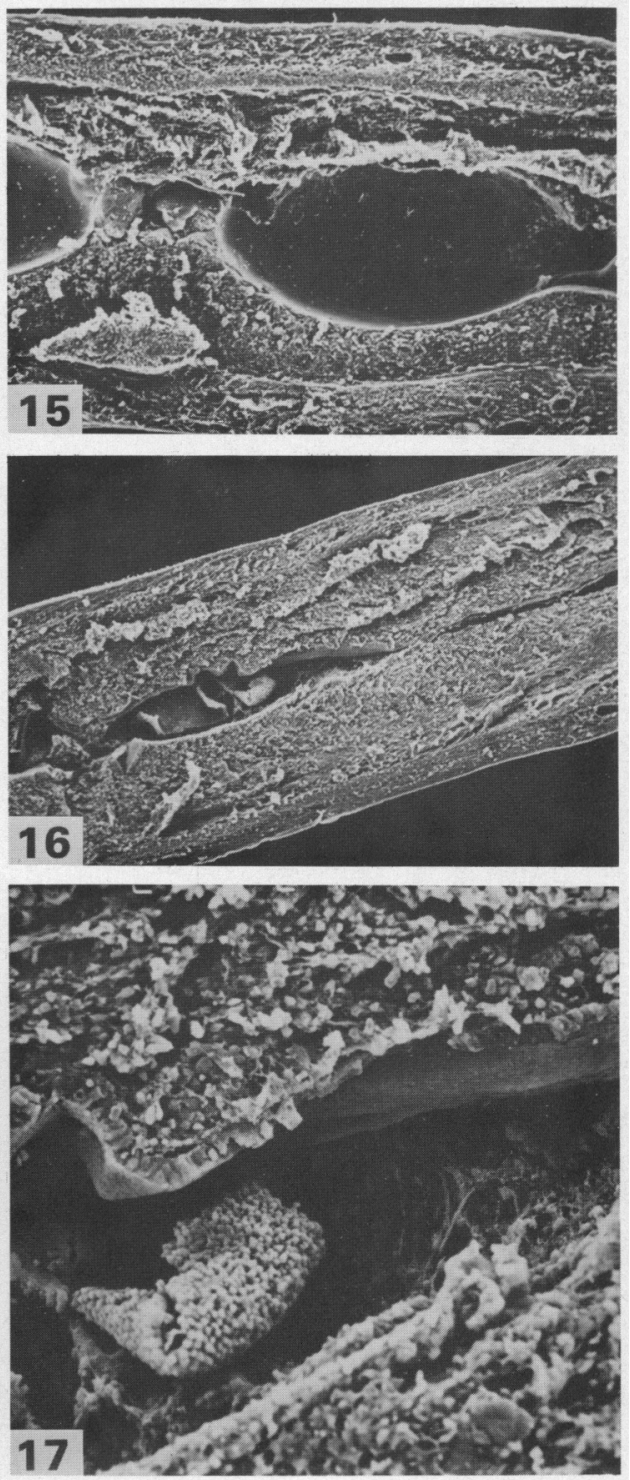
Evaluation of damage. To quantitate damage produced by flushing, transverse sections were randomized and scored blind (one per uterine horn). After several weeks slides were re-randomized and again scored blind by the same observer. Agreement between the two sets of scores was excellent; the results used are the first set. Quantal $(0,1)$ or semiquantal $(0,1,2)$ scores were based on the following criteria.

Luminal closure: 1, closed (Pl. 1, Fig. 1); 0, open (P1. 1, Fig. 2).

Leaching of the luminal epithelium: this was apparent as a diminution in toluidine blue staining of nuclei and cytoplasm compared with the dense staining of sham-flushed controls. The latter (Pl. 1, Fig. 1) were given a score of 0 . Flushed uteri showing major leaching from at least one quarter of the epithelium (Pl. 1, Fig. 2) were given a score of 2. Those intermediate between these two extremes were given a score of 1 .

Endometrial splitting: when there was none the section (e.g. Pl. 1, Fig. 1) was given a score of 0 . When only the luminal epithelium was split, the score was 1; when both epithelium and the underlying connective tissue stroma were split (Pl. 1, Fig. 2), the score was 2.

Passage of fluid into stroma (oedema) : when the stromal cells were densely packed as in shamflushed controls (Pl. 1, Fig. 1) the score was 0 . When the section showed extensive intercellular 'oedema' with swelling and apparent leaching of stromal cells (Pl. 1, Fig. 2) the score was 2. Sections showing degrees of 'oedema' intermediate between these two extremes were given a score of 1 .

\section{PLATE 2}

SEM views of anti-mesometrial lumina of uteri of ovariectomized mice flushed or sham-flushed with $0.5 \mathrm{ml}$ isotonic saline on Day 3 of progesterone/oestrogen treatment.

Figs 6-8. Closed lumina of sham-flushed horns showing apposition of epithelial cells. Fig. 6, $\times 160$; Fig. $7, \times 560$; Fig. $8, \times 1600$.

Fig. 9. Flushed horn; lumen dilated; rupture of lumen restricted to the extreme antimesometrial region. $\times 80$.

Fig. 10. High-power view of another flushed horn. The epithelial surface is locally intact, but there are many erythrocytes, leucocytes and fragments of unidentified debris on the surface. $\times 1600$.

Fig. 11. High-power view of another flushed horn showing an area of anti-mesometrial splitting with ruptured epithelial cells and droplets of fluid in the stroma: compare with stroma in Fig. 8. $\times 1600$.

\section{PLATE 3}

Scanning electron microscope views of flushed and sham-flushed uteri from mice on Day 5 of pregnancy.

Figs $12 \& 13$. Views of the area around an implanting blastocyst in a sham-flushed horn showing alignment of stromal cells around the implantation site (Fig. 12, $\times 160$; Fig. 13, $\times 560$ ). In areas where luminal epithelium was clearly visible the appearance was like that in P1. 2, Figs 6-8.

Figs 14-16. Views of uterine horns flushed early on Day 5 showing distension of the uterine lumen with varying degrees of damage and epithelial stripping upstream from putative implantation sites. The direction of flushing was in all cases from right to left. Fig. 14, $\times 56$; Fig. 15, $\times 80$; Fig. 16, $\times 56$.

Fig. 17. Higher power view of central area of Fig. 16 showing stripping of luminal cells and passage of fluid into the connective tissue stroma. $\times 320$.

Fig. 18. Higher power view of another uterine horn flushed early on Day 5 of pregnancy showing an area in which the flushing fluid has peeled away a layer of epithelial cells by basal rupture exposing the nuclei and releasing cell sap. $\times 1200$. 
Statistical analysis. When appropriate, results were analysed by a non-parametric median test (Bradley, 1968).

\section{Results}

\section{Ovariectomized mice}

In mice given progesterone and oestradiol for 3-4 days, all fluids produced the same type of damage, whether large or small volumes were used (Tables 1 \& 2). In transverse section most shamflushed uteri had closed lumina and densely packed stromal tissue (Pl. 1, Fig. 1). Sections from flushed uteri showed luminal distension, leaching of luminal cell cytoplasm and nuclei, splitting of the basement membrane, and passage of fluid into the stroma with distension of the intercellular spaces giving the appearance of oedema (P1. 1, Fig. 2). Stromal tissue was often split open with leaching of stromal cell cytoplasm and nucleoplasm and rupture of blood vessels. Luminal epithelial leaching was always maximal anti-mesometrially, and endometrial splitting was always confined to the anti-mesometrial cleft (P1. 1, Fig. 2; Pl. 2, Fig. 9). Actual removal of luminal epithelial cells seemed to be rare.

Transmission electron microscopy confirmed the light microscope observations. In the shamflushed horn of a mouse killed on Day 4 of treatment, opposing epithelial microvilli interdigitated closely and the cytoplasmic ground substance was dense (Pl. 1, Figs 3 \& 4). The flushed horn showed an extensive 'lumen' and the epithelial surface had been disrupted. Although the surface membrane appeared intact the 'lumen' contained membranous fragments and vacuoles (Pl. 1, Fig. 5). Most cells had lost ground substance and sometimes nucleoplasm; there was extensive disruption of epithelial and stromal mitochondria and cytoplasmic vacuolation.

Scanning electron microscopy of uteri flushed with saline on Day 3 or 4 of progesterone and oestradiol treatment confirmed that luminal splitting, although extensive longitudinally, was confined to the anti-mesometrial cleft, and that few epithelial cells were actually removed (Pl. 2, Fig. 9). Most flushed lumina contained erythrocytes (Pl. 2, Fig. 10) presumably derived from the ruptured vessels seen in wax sections.

In view of the damage produced by seemingly mild flushing, experiments were carried out to determine how it varied with fluid type and volume, and with an animal's endocrine status. In mice treated with progesterone and oestradiol for 3-4 days flushing with $0.5 \mathrm{ml}$ isotonic saline, PBS or Tris-glycine buffer produced similar degrees of endometrial damage (Table 1). Accordingly, differences in fluid type are ignored in Table 2, which summarizes the effects of fluid volume and hormone status. All flushed horns showed some degree of damage compared with the sham-flushed horns. Damage increased with increasing fluid volume, but within hormone treatments, increases were statistically significant in only 2 cases, both of which involved endometrial splitting. As little as $0.1 \mathrm{ml}$ produced substantial damage in the uteri of progesterone-treated mice. Whether fluidvolume differences are taken into account or not, the major determinant of the amount of damage

Table 1. Damage produced in the endometria of ovariectomized mice, given progesterone and oestrogen for 3-4 days, by flushing different fluids through the uterine lumen

\begin{tabular}{lrrrr}
\hline & & \multicolumn{3}{c}{ Score (mean \pm s.e.m.) } \\
\cline { 3 - 5 } \multicolumn{1}{c}{ Fluid $(0.5 \mathrm{ml})$} & $\begin{array}{c}\text { No. of } \\
\text { uteri }\end{array}$ & $\begin{array}{c}\text { Epithelial } \\
\text { leaching }\end{array}$ & $\begin{array}{c}\text { Endometrial } \\
\text { splitting }\end{array}$ & $\begin{array}{c}\text { Stromal } \\
\text { oedema }\end{array}$ \\
\hline Tris-glycine buffer & 19 & $1 \cdot 7 \pm 0 \cdot 1$ & $1 \cdot 1 \pm 0.2$ & $1 \cdot 4 \pm 0.2$ \\
Isotonic saline & 9 & $1 \cdot 8 \pm 0.2$ & $1.4 \pm 0.3$ & $1 \cdot 7 \pm 0.2$ \\
Phosphate-buffered saline & 9 & $1.9 \pm 0.1$ & $1 \cdot 3 \pm 0.4$ & $1 \cdot 4 \pm 0 \cdot 3$ \\
\hline
\end{tabular}

None of the differences significant at $P=0.05$; median test, $\chi_{1}^{2}$. 
was the animal's endocrine status. Thus epithelial leaching, endometrial splitting and stromal oedema were minimal in untreated or oestradiol-treated mice, increased in those given progesterone and again in those given progesterone and oestradiol for 3 days, becoming maximal in mice so treated for 4 days. This trend over the 4 hormone-treatment groups is seen most clearly by comparison of uteri flushed with $0.5 \mathrm{ml}$ fluid. Analysis of the overall differences between these 4 groups showed that increases in the three types of damage were all statistically significant (Table 2).

\section{Pregnant mice}

On the afternoon of Day 4 of pregnancy ( $84 \mathrm{~h}$ post coitum) embryo implantation is at its earliest stage, or has not started (Finn \& McLaren, 1967). At this time no uteri showed Pontamine Blue sites and transverse sections from flushed horns showed damage similar to that seen in progesteronetreated ovariectomized mice (Table 3). On the morning of Day 5, embryo implantation was well under way: 6/7 uteri showed distinct Pontamine Blue sites and sections of sham-flushed horns

Table 2. Effects of fluid volume and endocrine status on endometrial damage produced by uterine flushing in ovariectomized mice

\begin{tabular}{|c|c|c|c|c|}
\hline \multirow{2}{*}{$\begin{array}{l}\text { Hormone } \\
\text { treatment/ } \\
\text { fluid volume }\end{array}$} & \multirow[b]{2}{*}{$\begin{array}{l}\text { No. total } \\
\text { (closed) }\end{array}$} & \multicolumn{3}{|c|}{ Mean score \pm s.e.m. } \\
\hline & & $\begin{array}{l}\text { Epithelial } \\
\text { leaching }\end{array}$ & $\begin{array}{l}\text { Endometrial } \\
\text { splitting }\end{array}$ & $\begin{array}{l}\text { Stromal } \\
\text { oedema }\end{array}$ \\
\hline \multicolumn{5}{|c|}{ No progesterone } \\
\hline Sham & $10(0)$ & $0 \cdot 0$ & $0 \cdot 1 \pm 0 \cdot 1$ & 0.0 \\
\hline $0.2 \mathrm{ml}$ & $6(0)$ & $0.8 \pm 0.4$ & $\frac{1}{0}$ & $0.5 \pm 0.3$ \\
\hline $0.5 \mathrm{ml}$ & $16(0)$ & $0.8 \pm 0.1$ & $\dagger 0.4 \pm 0.1$ & $0.4 \pm 0.2$ \\
\hline \multicolumn{5}{|c|}{ Progesterone $2-4$ days } \\
\hline Sham & $10(0)$ & $0 \cdot 0$ & $0 \cdot 0$ & $0 \cdot 0$ \\
\hline $0.2 \mathrm{ml}$ & $12(0)$ & $1 \cdot 1 \pm 0 \cdot 2$ & $0.6 \pm 0.2$ & $0.7 \pm 0.3$ \\
\hline $0.5 \mathrm{ml}$ & $10(0)$ & $1 \cdot 6 \pm 0 \cdot 1 * * *$ & $0.8 \pm 0.3$ & $0.9 \pm 0.3$ \\
\hline \multicolumn{5}{|c|}{ Progesterone + oestradiol for 3 days } \\
\hline Sham & $26(18)$ & 0 & 0 & $0 \cdot 1 \pm 0 \cdot 1$ \\
\hline $0.1-0.2 \mathrm{ml}$ & $14(0)$ & $1 \cdot 4 \pm 0.2$ & $0.4 \pm 0.2$ & $1.4 \pm 0.2$ \\
\hline $0.5 \mathrm{ml}$ & $26(0)$ & $1 \cdot 7 \pm 0 \cdot 1^{* * *}$ & $1 \cdot 0 \pm 0.2$ & $1.4 \pm 0.2^{* * *}$ \\
\hline $2.0 \mathrm{ml}$ & $5(0)$ & $1 \cdot 8 \pm 0.2$ & $+2 \cdot 0 \pm 0.0$ & $2 \cdot 0 \pm 0.0$ \\
\hline \multicolumn{5}{|c|}{ Progesterone + oestradiol for 4 days } \\
\hline Sham & $16(15)$ & 0 & 0 & $0.1 \pm 0.1$ \\
\hline $0.5 \mathrm{ml}$ & $11(0)$ & $1 \cdot 9 \pm 0 \cdot 1^{* * *}$ & $1 \cdot 6 \pm 0 \cdot 2^{* *}$ & $1.7 \pm 0.1^{* *}$ \\
\hline $2.0 \mathrm{ml}$ & $5(0)$ & $2 \cdot 0 \pm 0.0$ & $1.4 \pm 0.4$ & $1.2 \pm 0.5$ \\
\hline
\end{tabular}

Individual treatment group comparisons:

$\dagger 0.01<P<0.05$ compared with lowest 'flush volume' treatment group within same hormone treatment group; median test, $\chi_{1}^{2}$.

${ }^{* *} 0.001<P<0.01 ;{ }^{* *} P<0.001$ compared with corresponding 'flush volume' treatment group in 'no progesterone' treatment group; median test, $\chi_{1}^{2}$.

Overall comparison between the 4 hormone treatment groups of uteri flushed with 0.5 $m l$ : 'leaching', $P<0.001$; 'splitting', $0.001<P<0.01$; 'oedema', $0.001<P<0.01$; median test, $\chi_{3}^{2}$.

showed well-developed primary decidual zones. Sections from flushed horns showed much more damage than did those taken on Day 4 (Table 3).

Scanning electron microscopy of sham-flushed uteri from pregnant mice or ovariectomized mice treated with progesterone and oestrogen usually showed a closed lumen (Pl. 2, Figs 6-8). Cutting the fixed tissue with a sharp scalpel caused little disruption of the tissues. The lumina remained closed, and epithelial cells at the 'cut' surface split apart at the intercellular surfaces 
Table 3. Endometrial damage produced by uterine flushing in pregnant mice as seen by light microscopy

\begin{tabular}{|c|c|c|c|c|c|c|}
\hline \multirow[b]{3}{*}{$\begin{array}{l}\text { Day of } \\
\text { pregnancy }\end{array}$} & \multirow[b]{3}{*}{ No. } & \multicolumn{5}{|c|}{ Mean score \pm s.e.m. } \\
\hline & & \multicolumn{4}{|c|}{ Flushed horn } & \multirow{2}{*}{$\begin{array}{c}\begin{array}{c}\text { Sham-flushed } \\
\text { horn }\end{array} \\
\text { Closure }\end{array}$} \\
\hline & & Closure & $\begin{array}{l}\text { Epithelial } \\
\text { leaching }\end{array}$ & $\begin{array}{l}\text { Endometrial } \\
\text { splitting }\end{array}$ & $\begin{array}{l}\text { Stromal } \\
\text { oedema }\end{array}$ & \\
\hline 4 & 17 & 0 & $0.9 \pm 0.2$ & $0.8 \pm 0.2$ & $0.8 \pm 0.2$ & $0.4 \pm 0.1$ \\
\hline 5 & 7 & 0 & $1.4 \pm 0.3$ & $1.6 \pm 0.3$ & $1 \cdot 1 \pm 0.3$ & $1 \cdot 0 \pm 0$ \\
\hline
\end{tabular}

rather than along intracellular planes. In several instances the cut passed through implanting blastocysts of the Day 5 pregnant uteri with no evidence of disruption of the site, which was easily identified by the alignment of the surrounding stromal cells (Pl. 3, Figs $12 \& 13$ ).

Scanning electron microscopy of flushed uteri from pregnant mice showed a form of damage not seen in ovariectomized animals. This consisted of the rupture and stripping of large sheets of luminal epithelial cells from the basement membrane (Pl. 3, Figs 14-18), occasionally with the basement membrane splitting away from the stroma, and more extensive passage of the flushing fluid from the lumen into the connective tissue. Such incursions were easily recognized by the numerous droplets along the fibres of the connective tissue (Pl. 2, Fig. 11). This type of damage is associated with closure of the uterine lumen and both increase in frequency between Days 4 and 5 of pregnancy. Of 17 uteri flushed on Day 4, the contralateral sham-flushed horns were open in 6 . In these 6 animals the flushed horns were dilated but only 2 showed anti-mesometrial epithelial splitting; the remainder showed little damage, although 2 contained many erythrocytes and debris. In 11 animals in which the sham-flushed horns had a closed lumen, 3 of the flushed horns showed little damage, but 8 showed disruption and removal of sheets of epithelium and massive fluid incursions into the stroma. On Day 5, all contralateral sham-flushed horns were closed and 6 of the 7 uteri showed this gross damage: the one that did not lacked Pontamine Blue sites.

\section{Discussion}

Flushing progestational mouse uteri with small quantities of fluid produces so much damage to the endometrium that some caution should be applied before describing the proteins contained in such flushings as 'luminal fluid' proteins, or for implying that they are secreted by luminal or glandular cells. My results show that many are probably derived from luminal and stromal cell-sap and nucleoplasm, intercellular fluid and blood.

The amount and type of damage changes with the endocrine status of the animal, and increases at the time of embryo implantation. Thus changing profiles of 'luminal fluid' proteins which have been interpreted as reflecting altered patterns of synthesis or secretion, and invoked as playing a crucial role in the regulation of implantation in mice (Aitken, 1979), probably largely reflect changing patterns of damage produced by flushing. In particular, rupture of stromal blood vessels could account for increased 'secretion' of serum proteins into the lumen between Days 4 and 5 of pregnancy (Gore-Langton \& Surani, 1976; Aitken, 1977). By Day 5 embryo implantation is so 
advanced that putative increases in protein synthesis/secretion at this time would in any case be consequences rather than causes of implantation.

Why should flushing cause so much damage in the progestational uterus compared with the non-progestational organ? In untreated ovariectomized mice the uterine lumen is open, and dye solutions instilled in volumes of up to $1-2 \mu \mathrm{l}$ via the cervix or ovarian tips will fill the lumen, flowing along it easily without meeting resistance or distending it. Flushing such uteri with as little as $0 \cdot 1 \mathrm{ml}$ fluid involves amounts $>50$ times the luminal volume and presumably sets up substantial hydrostatic pressure even though producing little damage. Progesterone treatment, which induces effective obliteration of the uterine lumen (Martin \& Finn, 1970), and treatment with progesterone plus oestrogen which induces further uterine closure (Pollard \& Finn, 1973), possibly as a result of increased adhesiveness of the epithelial cell surface (Nilsson, 1967), would greatly increase luminal resistance to passage of fluids and the hydrostatic pressures developed during flushing.

When 5-10 $\mu$ l fluid are instilled into progestational mouse uteri with a microsyringe to induce decidualization (Martin, 1979), there is always an initial resistance before fluid passes down and dilates the lumen. A similar phenomenon was noticed when flushing uteri from pregnant and progesterone-treated mice; initial careful depression of the plunger of the flushing syringe did not produce immediate flow of fluid through the uterine lumen, instead there was a marked resistance. As further pressure was applied the uterus suddenly 'gave', ballooned out and twisted and writhed as fluid squirted from the cervical end. No uteri split, fluid always passed through completely, to exit from the cervical end. It is easy to imagine the hydrostatic pressure splitting the luminal epithelium and stroma apart to force fluid into the stromal tissues with the subsequent turbulent flow rupturing tissues and cells and leaching out cellular constituents. It seems likely that the initial 'explosive' passage of fluid through the lumen is the most damaging phase of flushing. This would account for the relatively large amount of damage produced by flushing volumes as small as $0.1 \mathrm{ml}$.

Flushing produced more damage in pregnant than in non-pregnant progestational uteri although the latter were smaller and the lumen was closed in both cases. This suggests that the presence of blastocysts increases the amount of damage. One mechanism was apparent in Day 5 pregnant uteri in which implantation was well advanced. Here, implantation sites clearly formed nodes of resistance to passage of fluid so that the 'upstream' lumen was dilated, the epithelium split apart and fluid forced in to the stroma around the implantation site (Pl. 3, Figs 14-16). In these cases the basis of resistance could be diminution in potential luminal cross section because of growth of decidual tissue. This would not account for similar damage seen in Day 4 pregnant uteri, before development of a decidual reaction.

Progesterone appears to enhance circular muscle tone in the mouse uterus (Martin, 1979) and Day 4 pregnant uteri are characteristically long and thin at autopsy. In this they resemble uteri from progesterone-treated ovariectomized mice. However, they frequently show discrete patches of circular muscle contraction of an intensity that blanches the uterus locally (unpublished observations). Circular contractions of comparable intensity only occur in progesterone-treated ovariectomized mice after fluid/sham instillation, and then along the length of the uterus (Martin, 1979). Perhaps in pregnant uteri each local contraction is a local reaction to a blastocyst, initiated as the lumen, under the influence of progesterone, closes down around the embryo. Whether this is true or not, the sphincter-type actions of localized circular muscle contractions would produce foci of resistance to flushing by limiting the cross-sectional area of the lumen, and thus have effects similar to those of early decidualization. The experiments of Milligan \& Martin (1984) have demonstrated that hydrostatic pressures generated during uterine flushing are significantly increased in progestational and pregnant uteri.

I thank Rosemary Johnson for routine histology and processing the SEM specimens; Richard Newman for TEM; and the Photography Department of the Imperial Cancer Research Fund for services too many and varied to mention. 


\section{References}

Aitken, R.J. (1977) Changes in the protein content of mouse uterine flushings during normal pregnancy and delayed implantation and after ovariectomy and oestradiol administration. J. Reprod. Fert. 50, 29-36.

Aitken, R.J. (1979) Tubal and uterine secretions; the possibilities for contraceptive attack. J. Reprod. Fert. 55, 247-254.

Bradley, J.V. (1968) Distribution Free Statistical Tests. Prentice-Hall, Englewood Cliffs.

Fagg, B., Martin, L., Rogers, L., Clark, B.F. \& Quarmby, V. (1979) A simple method for producing pure homogenates of uterine luminal epithelial cells. J. Reprod. Fert. 57, 335-338.

Finn, C.A. \& Martin, L. (1969) Hormone secretion during early pregnancy in the mouse. $J$. Endocr. 45, 47-65.

Finn, C.A. \& Martin, L. (1972) Endocrine control of the timing of endometrial sensitivity to a decidual stimulus. Biol. Reprod. 7, 82-86.

Finn, C.A. \& McLaren, A. (1967) A study of the early stages of implantation in mice. J. Reprod. Fert. 13, 259-267.

Gore-Langton, R.E. \& Surani, M.A.H. (1976) Uterine luminal proteins of mice. J. Reprod. Fert. 46, 271274.

Martin, L. (1979) Early cellular changes and circular muscle contraction associated with the induction of decidualization by intrauterine oil in mice. J. Reprod. Fert. 55, 135-139.

Martin, L. \& Finn, C.A. (1970) The effects of an intrauterine device on uterine cell division and epithelial morphology during early pregnancy in the mouse. $J$. Endocr. 48, 347-354.
Martin, L. \& Finn, C.A. (1979) Varying effects of an IUD on decidualization in mice. $J$. Reprod. Fert. 55, 125133.

Martin, L., Finn, C.A. \& Carter, J. (1970) The effects of progesterone and oestradiol-17ß on the luminal epithelium of the mouse uterus. J. Reprod. Fert. 21, 461469.

Mayer, G., Nilsson, O. \& Reinius, S. (1967) Cell membrane changes of uterine epithelium and trophoblast during blastocyst attachment in rat. Z. Anat. EntwGesch. 126, 43-48.

Milligan, S.R. \& Martin, L. (1984) The resistance of the mouse uterine lumen to flushing and possible contamination of samples by plasma and interstitial fluid. J. Reprod. Fert. 71, 81-87.

Nilsson, O. (1967) Attachment of rat and mouse blastocysts onto uterine epithelium. Int. J. Fert. 12, 5-13.

Pollard, R.M. \& Finn, C.A. (1973) Ultrastructure of the uterine epithelium during the hormonal induction of sensitivity and insensitivity to a decidual stimulus in the mouse. J. Endocr. 55, 293-298.

Pratt, H.P.M. (1977) Uterine proteins and the activation of embryos from mice during delayed implantation. J. Reprod. Fert. 50, 1-8.

Surani, M.A.H. (1975) Hormonal regulation of proteins in the uterine secretion of ovariectomized rats and of the implications for implantation and embryonic diapause. J. Reprod. Fert. 43, 411-417.

Surani, M.A.H. (1977) Qualitative and quantitative examination of the proteins of rat uterine luminal fluid during pro-oestrus and pregnancy and comparison with those of serum. J. Reprod. Fert. 50, 281-287. 